\title{
Sustainability in Spanish Extensive Farms (Dehesas): An Economic and Management Indicator-Based Evaluation
}

\author{
P. Gaspar, ${ }^{1}$ F. J. Mesias, ${ }^{2}$ M. Escribano, ${ }^{3}$ and F. Pulido ${ }^{4}$ \\ Authors are ${ }^{1}$ Assistant Professor and ${ }^{3}$ Associate Professor, Department of Animal Production and Food Science, and ${ }^{2}$ Associate Professor and \\ ${ }^{4}$ Professor, Department of Economics, University of Extremadura, 06071 Badajoz, Spain.
}

\begin{abstract}
The dehesa is defined as an agroforestry system that is characteristic of the southwestern Iberian Peninsula, where grassland is combined with evergreen species of the genus Quercus. Those systems have been gradually transformed from the Mediterranean forest into a unique kind of pastoral woodland by means of an agricultural use. Dehesas occupy more than 6 million ha, and the livestock systems that are based in them are of vital importance for their sustainability. The present work classifies, describes, and evaluates the sustainability of these systems in the Spanish region of Extremadura (southwestern Spain). To this end, we apply a methodological adaptation of the Framework for the Evaluation of Management Systems incorporating Sustainability Index (MESMIS). MESMIS is based on the evaluation of basic attributes of sustainability from indicators that allow one to make a simultaneous and comparative analysis of different types of farms. For the study, 69 farms were selected at random, and were classified using multivariate techniques into four types according to their level of intensification and productive orientation. The results were used to obtain an overall value of sustainability from a technical economic perspective for each farm type present in the dehesa. The mixed systems (beef cattle-sheep-Iberian pigs) have been found to be the most sustainable in general terms. The high-stocking rate sheep dehesas are the least sustainable, although at present, they are the most profitable. The other two groups analyzed, "low-stocking rate sheep farms" and "beef cattle farms," had intermediate and similar scores. Mixed livestock dehesa farms are the closest to the traditional systems with a highly diverse production, an optimal use of the system's resources, and little dependence on external subsidies. In the present context, with uncertainties about European Union subsidies, this type of farm should be a goal for dehesa farmers.
\end{abstract}

\section{Resumen}

Los sistemas agroforestales de dehesas se localizan en el suroeste de la Península Ibérica ocupando una extensión de más de 6 millones de hectáreas. Los sistemas ganaderos que en ellos se asientan son de vital importancia para su sostenibilidad. Este trabajo clasifica, describe y evalúa la sostenibilidad de estos sistemas en la región española de Extremadura (SO España). Para ello se aplica una adaptación metodológica del marco MESMIS (Marco de Evaluación de Sistemas de Manejo incorporando indicadores de Sostenibilidad). Este método se basa en la valoración de atributos básicos de sostenibilidad a partir de indicadores que permiten hacer un análisis simultáneo y comparativo de distintas tipologías de explotaciones. Para el desarrollo del trabajo se ha partido de 69 explotaciones seleccionadas aleatoriamente. Se emplearon técnicas de estadística multivariadas clasificandolas en cuatro tipologías según su nivel de intensificación y orientación productiva. De los resultados se obtuvo un valor global de sostenibilidad para cada tipología de explotación presente en la dehesa desde una perspectiva técnico-económica. Los sistemas mixtos (vacuno-ovinoporcino ibérico) han resultado ser los más sostenibles en términos generales. Las dehesas de ovino con alta carga ganadera son las menos sostenibles, aunque en la actualidad son las más rentables. Los otros dos grupos analizados, "explotaciones ovinas con carga baja" y "explotaciones de bovinos", tienen puntuaciones intermedias y similares. Las dehesas con ganado mixto son las más cercanas a los sistemas tradicionales, con una producción altamente diversificada, un aprovechamiento óptimo de los recursos del sistema y una baja dependencia de los subsidios. En la situación actual, con incertidumbres acerca de los subsidios comunitarios, este tipo de explotación debería ser el objetivo de las explotaciones de dehesa.

Key Words: livestock production, management strategies, MESMIS, rangelands, sustainability indicators

\section{INTRODUCTION}

Society today, although not closely involved in the actual practice of farming, is concerned with the potential environ-

Research was funded by the European Union's INTERREG IIIA initiative as part of the project SP4.E13 "Development of a system of information for the environmental and economic management of the dehesa/montado ecosystem in Extremadura and Alentejo."

Correspondence: Paula Gaspar, Dept Producción Animal y Ciencia de los Alimentos, Escuela de Ingenierías Agrarias, Universidad de Extremadura, Ctra Cáceres s/n 06071, Badajoz, Spain.Email: pgaspar@unex.es

Manuscript received 14 November 2007; manuscript accepted 9 November 2008. mental, social, and health impacts of farming and with its sustainability (Gibon et al. 1999). The concept of sustainability includes the need to consider not only short-term economic impacts, but also long-term social and ecological impacts. This requires economically efficient production systems with optimal use of the resources, particularly those involving complex ecological communities such as extensive livestock systems depending on native vegetation communities (Boyazoglu 2002).

The dehesa is defined as an agroforestry system that is characteristic of the Iberian Peninsula where native herbaceous vegetation and evergreen species of the genus Quercus provide the foundation for extensive farming enterprises that include 
beef cattle (Bos taurus), sheep (Ovis aries), Iberian pigs (Sus scrofa domesticus), and, to a lesser extent, goats (Capra hircus). The livestock farming systems of the dehesa are traditional systems based on productive diversity, so that one commonly finds the simultaneous use of multiple livestock species to make better use of the different resources. The ruminants make use of the pasture, gleanings from cereal crops, stubble, and fallow land, and the Iberian pigs in their final phase of fattening feed on the acorns of, mainly, holm oak (Quercus ilex subsp. ballota), but also cork (Quercus suber) and gall oaks (Quercus faginea). Dehesas are considered to be the most extensive, diverse, and low-intensity land use systems in Europe (Bignal et al. 1995). The average size of the farms is around 500 ha, varying from 250 ha to 1500 ha (Porras 2000; Escribano et al. 2001; Plieninger and Wilbrand 2001; Plieninger et al. 2004; Milán et al. 2006). The mean stocking rate is 0.37 livestock units (LU) $\cdot \mathrm{ha}^{-1}$ (Escribano et al. 2002b), much lower than other European systems that are also considered extensive (Colson and Chatelier 1996; Milán et al. 2003; Serrano et al. 2004; Lasseur 2005). These systems also include crop production (fundamentally for reuse as animal feed), forestry (cork and firewood), and game. Mixed crop and livestock farming systems are regarded as integrated and diversified systems where the integration is fundamental to increase their sustainability (Ronchi and Nardone 2003).

The importance of dehesa systems is immediately seen in the expanse of territory that they occupy. In Spain this is approximately 5.8 million ha, and in southern Portugal (where the term for dehesa is 'montado') there are another 0.5 million ha (Joffre et al. 1999). Also, they play an important environmental and social role, because the economic sectors based on dehesas are of vital importance for the regions in which they are located. Additionally, maintaining historical, recreational, and landscape values are of increasing social concern. The interest in studying the sustainability of dehesas lies in the role played by their extensive livestock systems in conserving these complex and particularly sensitive ecosystems. Grassland, woodland, and livestock complement each other, and when they are maintained in equilibrium they preserve soil moisture, recharge the topmost layers with nutrients, and prevent the invasion of scrub (Olea and San Miguel-Ayanz 2006). The livestock can therefore be said to protect the soil and the vegetation in such a climatically and lithologically difficult area. Human intervention plays a key role in the maintenance of the dehesa ecosystem; the use of appropriate cultural practices (such as grazing suited to the system's capacity or forest regrowth) is vital for the conservation of the tree stratum. Sometimes, this intervention can also have negative effects, mainly due to overgrazing, which implies an intensification of the traditional management system, usually in an attempt to improve the profitability (Escribano et al. 2006).

Thompson and Nardone (1999) suggest that the sustainability of extensive systems of livestock production can be applied to the complex relationships that exist between stocking rates, grassland, scrub, and wildlife. These elements of grazing systems can remain in equilibrium for prolonged periods of time, but an imbalance can appear suddenly as a result of a critical change in one of the elements (Díaz et al. 1997; Olea and San Miguel-Ayanz 2006).
In particular, the most significant change in the dehesas since the 1980s has been caused by the Common Agricultural Policy (CAP). Although the CAP has encouraged extensification, especially after its reform in 1992, the reference production levels fixed $\left(1.4-1.6 \mathrm{LU} \cdot \mathrm{ha}^{-1}\right)$ were far higher than those traditionally used in the dehesa, so that the result has been intensification of these systems (Escribano et al. 2001, 2002a). The European Union policy of subsidies has led dehesa farms to increase their production in order to attain a greater level of income and place themselves in an acceptable position of competitiveness with respect to other production systems. But the cost has been the overexploitation of such an important natural space as the dehesas. Figure 1 shows how the LUs of the different species present in the Extremadura dehesa have evolved over the last $20 \mathrm{yr}$. Bearing in mind the negative effects of this overgrazing on the conservation of the dehesa as an ecosystem-lack of regeneration of the wooded layer (Montero et al. 1998), and degradation and erosion of the soil (Schnabel 1997) — and that the intensification of these systems is tightly bound to the improvement of their profitability (Escribano et al. 2006), it seems necessary to find the balance that will allow the persistence of this ecosystem.

In this context, there is particular interest in the study of the sustainability of the dehesa livestock systems from a technical and economic perspective. To this end, we apply the evaluation framework proposed by Masera et al. (1999) and further developed by Lopez-Ridaura et al. $(2002,2005)$ in order to develop sustainability indices that can be easily understood by farmers and managers and that might be used in their decision making related to the livestock sector and local development.

\section{METHODS}

\section{The Study Area, Sampling, and Field Data Collection}

The study area was the region of Extremadura, in the southwestern quadrant of Spain between lat 37 $56^{\prime} 32^{\prime \prime}-$ $40^{\circ} 29^{\prime} 15^{\prime \prime} \mathrm{N}$ and long $4^{\circ} 38^{\prime} 52^{\prime \prime}-7^{\circ} 32^{\prime} 35^{\prime \prime} \mathrm{W}$ (reference system: European Datum 1950). It has a low population density, and approximately 2.2 million ha (more than $50 \%$ of the utilized agricultural area) is considered to be dehesa. The predominant tree species are oaks: holm oak (Q. ilex subsp. ballota), which is found in $80 \%$ of the dehesas, followed by cork oak (Q. suber), and then the Pyrenean oak (Quercus pyrenaica), gall oak (Q. faginea), and kermes oak (Quercus coccifera). The soils of the dehesa are acid, shallow, sandy loams of low fertility because of insufficient organic matter and a marked lack of phosphorus. These characteristics make them marginal for cereals (San Miguel 1994). The climate is continental Mediterranean. The annual mean temperatures range between $16^{\circ} \mathrm{C}$ and $17^{\circ} \mathrm{C}$. The summers are long, hot, and dry: the mean July temperature is usually over $26^{\circ} \mathrm{C}$, the maximum often surpassing $40^{\circ} \mathrm{C}$. The winters are normally mild with a mean temperature of $7.5^{\circ} \mathrm{C}$. Annual rainfall has an irregular distribution and varies between $300 \mathrm{~mm}$ and $800 \mathrm{~mm}$, with large variations between years (Granda et al. 1991; Hernández 1998; Espejo and Espejo 2006).

The data used in this work were collected by means of questionnaire surveys of holders of dehesa farms conducted in 2004 and 2005. The sample consisted of 69 farms representa- 


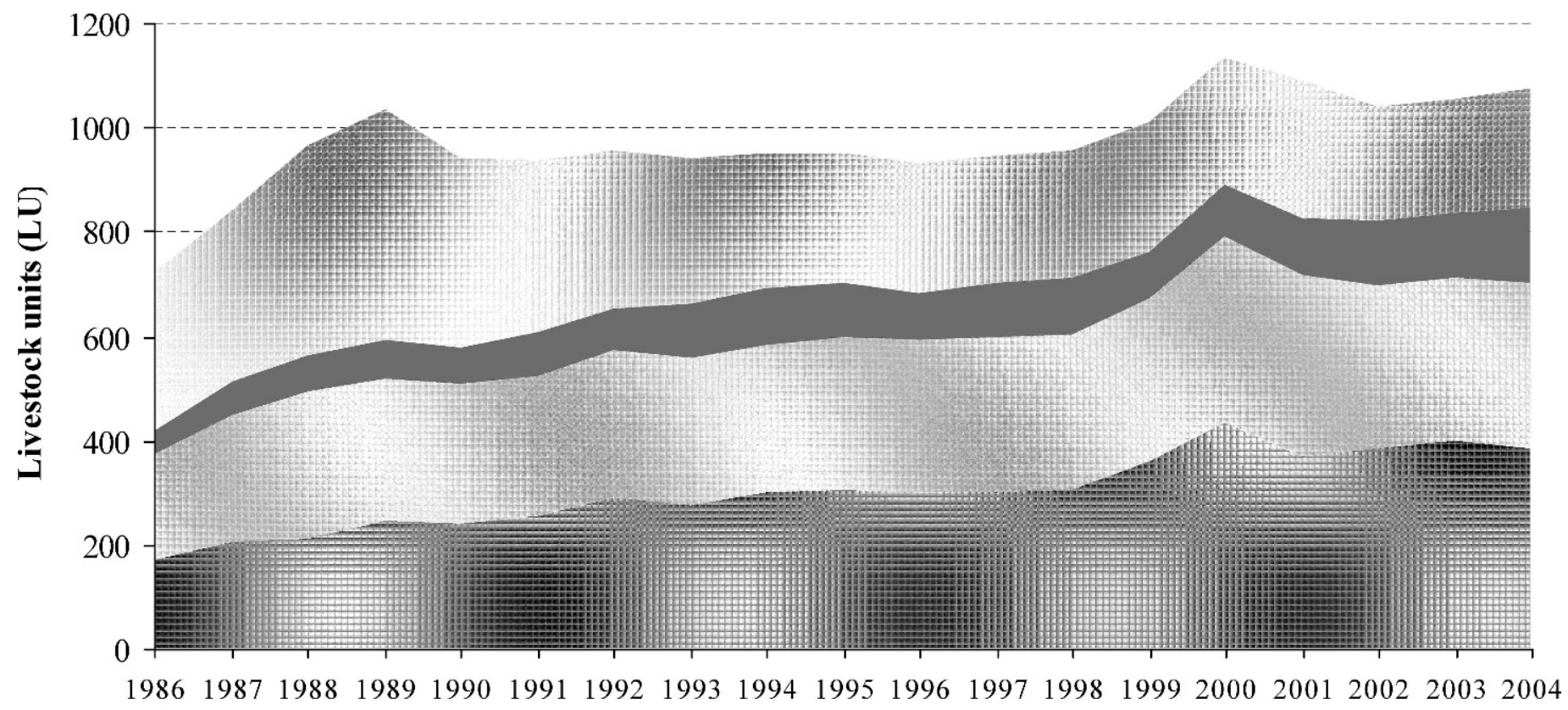

III Cattle (x 1000$)$

Sheep $(x 10$ 000)

- Pigs (x 1 000)

Goats (x 1000$)$

Source: MAPA (1987-2005)

Figure 1. Evolution of livestock censuses (in livestock units) in Extremadura in the period 1986-2004.

tive of Extremadura dehesa systems. They were selected at random following forestry, livestock, and economic size criteria. They form a homogeneous ecosystem in which extensive livestock raising predominates, with there also being unwooded zones of pasture and scrub with grazing.

\section{Evaluation of the Farms' Sustainability}

As the basis for the evaluation of the sustainability of livestock production systems in dehesa ecosystems, we used the Framework for the Evaluation of Management Systems incorporating Sustainability Index (MESMIS) proposed by Masera et al. (1999) and adapted by the present authors for application to dehesa systems. The MESMIS operative structure is a six-step cycle. The first three steps are devoted to characterizing the systems, identifying critical points, and selecting attributes that will be then used to define specific indicators for the environmental, social, and economic dimensions of sustainability. In the last three steps, those defined indicators are integrated (through qualitative, quantitative, or multiple-criterion techniques) in order to obtain a specific value that measures the sustainability of the system. This framework is of great practical applicability, and is easily adapted to different agrosystems. A review in English of this methodology is described in López-Ridaura et al. (2002, 2005).

The selection of the attributes, however, was one of the hardest tasks in the application of MESMIS because of the lack of consensus about the set of attributes to be used. Although different authors who have worked on sustainability in recent years have agreed that its evaluation has to be based on certain attributes of the system, the problem is that each has chosen and defined their own set of attributes. Even though many of these attributes coincide in essence, there are significant differences in nuance. The attributes considered by Smith and Dumanski (1994) include social security, ecological protection, economic viability, and cultural acceptability. Mitchell et al. (1995) add ecological integrity (e.g., protection of the environment), social equity, intragenerational equity, and intergenerational equity, which they term "futurity." Other authors have explicitly included such attributes as acceptability (Capillon and Genieve 2000) and equity (Conway 1994; Masera et al. 1999) in order to integrate the social dimension into the analysis, instead of considering only the basic attributes of sustainability. Aside from these exceptions, most of the attributes are such basic aspects of the systems as productivity, effectiveness, stability, and adaptability or flexibility.

Our evaluation was structured around five basic attributes of sustainability that will be described below. They were chosen as being the attributes that most coincided between authors and were the best suited to the technical and economic perspective taken in the present work. In the following paragraphs, we shall describe the attributes on whose basis the sustainability was evaluated and the indicators that will be used for each attribute.

Adaptability or Flexibility. This is the system's capability to find new levels of equilibrium, i.e., to continue being productive or, in a more general sense, profitable when faced with long-term changes in the environment (e.g., new economic or biophysical conditions). This attribute also includes the capability to actively seek new levels or strategies of production 
to improve the present situation. Dehesa systems have two critical points that work against their adaptability: the difficulty in reorienting their output, and their dependence on livestock-linked subsidies. The indicators selected try to evaluate both aspects.

Two of the indicators selected for the above attribute are percentage of wooded area and percentage of grassland with no tree cover. Those farms with a greater percentage of areas wooded with holm and cork oaks are considered to be more adaptable because of their greater productive diversity: wooded areas in dehesa farms provide not only food for the livestock, but many other additional and valuable outputs, such as cork or charcoal. Game hunting - and especially for big game such as deer (Cervus elaphus) or wild boar (Sus scrofa)-is another activity frequently developed in wooded dehesas. Wooded dehesas are believed to be less vulnerable to possible future changes in the environment, which is the essence of adaptability or flexibility, because they don't have an absolute dependence on the livestock sector.

Other indicators of productive diversity considered in this section are the percentages of each livestock species with respect to the total. Farms with a mix of livestock are at a lower level of risk when some crisis occurs in a sector (epizootics, for example), and can more easily modulate their production toward one species or another, and raise or lower the intensity of their output. Likewise, technical indicators such as the number of sows per boar (and cows per bull and ewes per ram) give an indication of the possibility of change in efficiency of production. Having males of different breeds makes it possible to raise either pure- or cross-bred animals, according to market conditions (sale for breeding, or sale for fattening). Included as an economic indicator is the ratio of dependence on subsidies.

Self-Reliance. This is the system's capacity to regulate and control its interactions with the outside. For the case of the dehesas, we selected indicators that measure the farms' dependence on external inputs, such as the purchase of animal feedstuffs and other intermediate consumption. The smaller the need for purchases, whether of raw materials or of external services, the more self-reliant the system. Other indicators selected were those related to the intermediate consumption that takes place within the farm, and the percentage of energy resources that the animals obtain directly from the pasture. The greater the value of these indicators, the lower the level of dependence. The economic indicator of leased or rented area conveys information of the same type: the greater the system's rented area, the greater the dependence and the lower the selfreliance.

Equity. This is the system's capacity to distribute fairly, both intra- and intergenerationally, the profits and costs related to the management of its natural resources (Masera et al. 1999; López-Ridaura et al. 2002). This attribute refers to the income distribution in the production systems. Its indicators are fundamentally measures of the number and type of persondays. It was considered that the greater the amount of labor employed by the farm, the more equitable the system.

Stability. This term refers to the system's property of possessing a state of dynamic economic stability. It implies that it is possible to maintain the profits provided by the system at a nondeclining level over time, under normal or average conditions. It is normally associated with the notion of constancy of output (or profits). The economic indicators for this attribute are the fixed capital and the percentage of owned area. Owner-run dehesa farms and those with greater capital investment (especially land capital) were considered to be more stable. The land capital figure, in particular, reflects a farm's productive condition, because those farms that have trees, better soils, and/or improved pastures show greater fixed capital value.

The stocking rate was considered to be an important indicator for this attribute because appropriate levels of livestock stocking rate contribute to the system's ecological stability in impeding the invasion of shrub (as is possible in cases of undergrazing; Peco et al. 2006) and in avoiding the degradation and erosion of the soil (as occurs in cases of overgrazing; Schnabel 1997). As stated by Gaspar et al. (2007), high-stocking rate dehesas are not necessarily those with the best pasture lands, but those that show higher purchase of feedstuff, since they are overgrazing their grasslands.

Finally, another indicator, such as percentage of breeders of autochthonous breeds, provides information on the system's biological diversity. A high percentage of autochthonous animals is considered to contribute to stability (Nahed et al. 2006). These autochthonous breeds, with genotypes adapted to the particularities of dehesa systems, have better chances to survive and breed in a harsh environment, with irregular rainfall distribution, droughts, high temperatures, scarcity of grasslands, etc.

Productivity. This is the capacity of the agroecosystem to provide the required level of goods and services. It represents the value of the attribute (yields, earnings, etc.) in a given period of time (the year of study or an average over a certain time interval). The economic indicators considered within this attribute were mainly income and balancing indicators (value added, net operating surplus, entrepreneurial income, and profitability rate) and the basic indicator of gross output. The method used for the design of the economic indicators was a microeconomic adaptation of the Economic Accounts of Agriculture and Forestry (European Communities 2000) with some methodological changes that have been implemented through several research works aimed at providing a rigorous measure of the economic resources of dehesa farms. The indicators considered are those related to livestock productivity: calves, lambs, and piglets sold per breeding female. For all of these indicators, the greater the value, the more productive the systems. Table 1 presents all the indicators used, together with their units.

\section{Computation of Sustainability Indices}

The following step was taken to compute indices of sustainability. This phase consisted of transforming the values obtained for the different indicators into homogeneous sustainability indices. Masera et al. (1999) indicate that in this stage one of the most critical points is the determination of a threshold or reference value for each indicator to be used in the evaluation. This involves identifying their maximum possible or optimal values with respect to sustainability, and their required or acceptable minimum values. 
Table 1. The indicators selected for each attribute, and their units.

\begin{tabular}{|c|c|c|}
\hline Attributes & Indicators $^{1}$ & Units \\
\hline \multirow[t]{8}{*}{ Adaptability } & Wooded UAA per total UAA & $\%$ \\
\hline & Pasture UAA per total UAA & $\%$ \\
\hline & Subsidies per total income & $\%$ \\
\hline & Cattle LU² per sheep LU & $\%$ \\
\hline & Swine LU per total LU & $\%$ \\
\hline & Cows per bull & Cows \\
\hline & Ewes per ram & Ewes \\
\hline & Sows per boar & Sows \\
\hline \multirow[t]{10}{*}{ Stability } & Owned UAA per total UAA & $\%$ \\
\hline & Total stocking rate & $\mathrm{LU} \cdot \mathrm{ha}^{-1}$ \\
\hline & Land fixed capital & $€ \cdot \mathrm{ha}^{-1}$ \\
\hline & Buildings fixed capital & $€ \cdot \mathrm{ha}^{-1}$ \\
\hline & Machinery fixed capital & $€ \cdot \mathrm{ha}^{-1}$ \\
\hline & Breeding livestock fixed capital & $€ \cdot \mathrm{ha}^{-1}$ \\
\hline & Percentage of autochthonous cattle & $\%$ \\
\hline & Percentage of autochthonous sheep & $\%$ \\
\hline & Percentage of Iberian pigs & $\%$ \\
\hline & No. of montanera fattened pigs & pigs $\cdot$ ha $^{-1}$ \\
\hline \multirow[t]{8}{*}{ Self-reliance } & Rented UAA per total UAA & $\%$ \\
\hline & Scrubland UAA per total UAA & $\%$ \\
\hline & Cultivated UAA per total UAA & $\%$ \\
\hline & Purchased animal feedstuff & $€ \cdot \mathrm{ha}^{-1}$ \\
\hline & Veterinary expenses & $€ \cdot \mathrm{ha}^{-1}$ \\
\hline & Intermediate consumption ${ }^{3}$ & $€ \cdot \mathrm{ha}^{-1}$ \\
\hline & Intraunit consumption ${ }^{4}$ & $€ \cdot \mathrm{ha}^{-1}$ \\
\hline & Percentage use of natural resources ${ }^{5}$ & $\%$ \\
\hline \multirow[t]{10}{*}{ Productivity } & Sales of livestock & $€ \cdot \mathrm{ha}^{-1}$ \\
\hline & Other sales & $€ \cdot \mathrm{ha}^{-1}$ \\
\hline & Gross output ${ }^{6}$ & $€ \cdot \mathrm{ha}^{-1}$ \\
\hline & Net value added ${ }^{7}$ & $€ \cdot \mathrm{ha}^{-1}$ \\
\hline & Net operating surplus ${ }^{8}$ & $€ \cdot \mathrm{ha}^{-1}$ \\
\hline & Net entrepreneurial income ${ }^{9}$ & $€ \cdot \mathrm{ha}^{-1}$ \\
\hline & Profitability rate & $\%$ \\
\hline & Calves sold per cow & $\%$ \\
\hline & Lambs sold per ewe & $\%$ \\
\hline & Piglets sold per sow & $\%$ \\
\hline \multirow[t]{4}{*}{ Equity } & Total AWU of the farm per 100 ha & AWU $\cdot 100 \mathrm{ha}^{-1}$ \\
\hline & Permanent AWU per 100 ha UAA & $\mathrm{AWU} \cdot 100 \mathrm{ha}^{-1}$ \\
\hline & Temporary AWU per 100 ha UAA & AWU $\cdot 100 \mathrm{ha}^{-1}$ \\
\hline & Family AWU per 100 ha UAA & AWU $\cdot 100 \mathrm{ha}^{-1}$ \\
\hline
\end{tabular}

${ }^{1}$ UAA indicates utilized agricultural area; LU, livestock unit; and AWU, annual work units.

${ }^{2} \mathrm{LU}$ is a measure of livestock grazing in agriculture. One LU is usually defined as the grazing equivalent of one adult dairy cow. Many different schemes exist, giving various values to the grazing effect of different types of animal. In this paper we have used the following equivalents adapted to dehesa systems: $1 \mathrm{cow}=1 \mathrm{LU} ; 1$ sheep $=0.12 \mathrm{LU} ; 1$ sow $=0.37 \mathrm{LU}$.

${ }^{3}$ Intermediate consumption represents the value of all goods and services used as inputs in the production process, excluding fixed assets whose consumption is recorded as fixed capital consumption (Gaspar et al. 2008).

${ }^{4}$ Agricultural products produced within the agricultural unit and used by the unit as inputs into the production process within the same accounting period (Gaspar et al. 2008).

${ }^{5}$ Percentage of energy resources that the animals obtain directly from the pasture.

${ }^{6}$ All the products of the agricultural activities. All agricultural output is recorded except that produced by units that produce solely for their own consumption.

${ }^{7}$ Measures the value created by all the agricultural output after the consumption of fixed capital. That output is valued at basic prices and intermediate consumption is valued at purchaser prices.

${ }^{8}$ Measures the yield from land, capital, and unpaid labor. It is the balance of the generation of income account, which indicates the distribution of income between the factors of production and the general government sector.

${ }^{9}$ Obtained by adding the interest received and then deducting rent (i.e., farm and land rents) and interest payments, measures the compensation of unpaid labor, remuneration from land belonging to units, and the yield arising from the use of capital.
Studies in the literature on how to establish thresholds of sustainability for indicators deal specifically with those of a biophysical nature (Smith and Dumanski 1994). In the socioeconomic area, it is very difficult to use general reference values (Masera et al. 1999). In the present work, we established certain optimal values for each indicator, selecting in each case the maximum, minimum, or percentiles of the sample according to the opinion given by experts in the field whom we consulted. For some indicators, the experts themselves established the optimum directly.

We benefited from the collaboration of a group of five experts related to dehesa livestock production (agronomists, veterinarians, and livestock farmers). They were given a table of all the indicators and their basic statistical descriptors (maximum, minimum, mean, and percentiles). In view of the lack of initial data relative to the dehesa ecosystem, it was decided that the optimal levels should lie within the range of the sample, because this was representative of the different dehesa subsystems. The experts were asked to choose one of the values given as optimal for each indicator, and only in extreme cases to give another value (this only occurred for the livestock stocking rate). The results of the experts' first opinion were summarized and presented to them again, to try to reach greater consensus. The final result is what appears in the present work.

Subsequently, we applied a methodological adaptation of the AMOEBA method (Ten Brink et al. 1991) to establish series of criteria to transform the original indicator values into percentage-of-sustainability indices to be applied to each farm. The AMOEBA approach is a model used to visually assess a system's condition relative to an optimal condition. It has been used extensively in assessing resource sustainability, such as marine ecosystems, soil conditions, agroecosystems, or even marketing, where it is used to assess consumer satisfaction. The model is circular with the various indicators positioned around the outside. Lines radiate from the center to the indicators, on a continuum from unsustainable (in the center) to sustainable (the outer ring). The optimal situation, when the system scores the highest degree of sustainability, would look like a circle.

For the indicators whose optimal value were chosen to be the maximum, the index was calculated as

Sustainability index $=($ indicator value/optimal value $) \cdot 100[1]$

For the indicators whose optimal value was chosen to be the minimum, the index was calculated as

Sustainability index $=($ optimal value $/$ indicator value $) \cdot 100[2]$

In this way, the more closely the index approaches $100 \%$, the greater the sustainability.

For the indicators whose optimal value were chosen to be some percentile, the mean, or a recommended value, if the value of the indicator was lesser than the optimal value, formula 1 was applied. If the value of the indicator was greater than the optimal value, then formula 2 was used.

It needs to be noted that there is not necessarily any direct relationship between the values of the indicators and the indices due to the indicator-index transformation. In some variables 
(cattle LU per sheep LU; swine LU per total LU; livestock stocking rate) it was established that exceeding (or not reaching) the optimum could penalize the farm (for example, for the livestock stocking rate, a value above the optimal implies overgrazing, and reduces the system's sustainability). In other variables (land fixed capital; buildings fixed capital; machinery fixed capital; breeding livestock fixed capital), if the figure exceeded $100 \%$, it was simply replaced by the $100 \%$ value (in machinery fixed capital, for example, that a farm exceeded the optimal value-either by having more machinery, or more expensive or newer machinery-was not considered to imply either improvement or reduction of sustainability).

\section{Characterization of the Systems}

The sustainability evaluation used a typology of dehesa farms established in a previous work (Gaspar et al. 2007). Fifty-two technical and economic variables were selected and, by means of multivariate statistical techniques, used to construct four dehesa farms typologies. Principal-component analysis allowed us to establish a valid model explaining $65.8 \%$ of the variance. The most significant components were "Iberian pig production" (explaining $20 \%$ of the variance of the model), and "ruminant species raised on the farm" ( $15 \%$ of the variance). A cluster analysis distinguished four types of farms: sheep farms at high and low stocking rates, beef cattle farms, and wooded farms with mixed livestock. The most profitable farms were those with either high overall livestock density or a high level of Iberian pig production. The main characteristics of the groups obtained were as follows:

Group 1. Farms oriented mainly to sheep production with low stocking rates. The wooded area of the farms was around $61 \%$, and near $50 \%$ were rented. The labor maintaining the farms is the lowest of all the groups, and was mainly permanent labor.

Group 2. Farms oriented mainly to beef production. The sizes of the farms and their wooded area both had characteristics that are similar to those of Group 1.

Group 3. Sheep farms with high stocking rates. They were characterized by being farms of smaller size and lacking wooded area. Their stocking rates were very high $\left(0.60 \mathrm{LU} \cdot \mathrm{ha}^{-1}\right)$, and the properties were $35 \%$ in a leased or rented regime. These farms used a high level of labor that was fundamentally family.

Group 4. Wooded dehesa farms of mixed beef cattle, sheep, and Iberian breeding sows. They were characteristically large, nearly entirely wooded estates owned by the holder.

\section{Statistical Analysis}

The present study used a nonparametric test (the KruskalWallis test) to compare the sustainability indices between the different groups of farms obtained in the characterization, after verifying that the distribution of the indices was nonnormal.

\section{RESULTS}

Table 2 gives the mean values obtained for each of the selected sustainability indicators, classified according to attribute for the four farm groups. Table 3 presents the calculated sustainability indices, with values that can range between 0 and 100 such that the closer to 100 , the better the farm in terms of sustainability. Finally, each farm is assigned a score for each attribute of sustainability, calculated as the mean of its corresponding indices.

Table 3 also shows the results of the Kruskal-Wallis test, which was applied to the sustainability indices to determine if significant differences in the sustainability indices between the groups of farms were found.

\section{Adaptability}

The indicators comprising this attribute are related to the possibility of change in the farms. In Table 2 , one observes that Group 4 is the most adaptable $(86.9 \%)$ showing significant differences in the majority of adaptability scores, and Group 3 has the lowest percentage for this attribute $(40.2 \%)$. The latter are farms basically without any wooded area and with a high dependence on CAP subsidies. Investment made in the property has been largely focused on improving or facilitating the management of sheep livestock, so that these systems are not very flexible when changes are introduced. The farms of Groups 1 and 2 occupy an intermediate position with an adaptability score of around $50 \%$.

\section{Self-Reliance}

The indicators for the self-reliance attribute were selected chiefly as relating to expenditure. The main difference in selfreliance between the four types corresponds to their level of intensification. In general terms, the two lower stocking rate groups, especially that of beef cattle, have less intermediate consumption, so that they would be more sustainable in regard to this attribute, whereas the farms with stocking rates greater than the optimal value present high values of intermediate consumption and greater wage-earner remuneration.

\section{Equity}

This attribute refers to the distribution of the profits obtained from the farms. The farms of Groups 1 and 2 are those with the most permanent labor, and therefore contribute most to stable employment, whereas in the farms of Group 3 the income distribution is less equitable, being fundamentally to nonwage-earning family labor. The mixed group is that which uses the most labor, distributed fairly evenly between permanent, temporary, and family, so that it is again the group that scores the highest. Table 2 lists the values of the equity indicators.

\section{Stability}

The indicators for this attribute show the system's capacity to maintain the profits provided by the system at a nondecreasing level over time, under normal or average conditions. The maintenance of a stocking rate that is suited to the resources provided by the system will clearly contribute to stability, and in this sense the Group 2 farms are the most sustainable in terms of this indicator.

The mixed farms were the most stable from having the highest capital indicators. With respect to the full-time presence of the holder, the farms of Group 3, those with the heaviest stocking rate, scored the highest. In sum, in terms of stability, 
Table 2. Mean values of the sustainability indicators for the four farm types. ${ }^{1}$

\begin{tabular}{|c|c|c|c|c|c|c|c|}
\hline \multirow[b]{3}{*}{ Attributes } & \multirow[b]{3}{*}{ Indicators } & \multicolumn{4}{|c|}{ Mean values } & \multirow[b]{3}{*}{ Optimal } & \multirow[b]{3}{*}{ Criteria } \\
\hline & & Low sheep & Beef & High sheep & Mixed & & \\
\hline & & $N=19$ & $N=23$ & $N=13$ & $N=14$ & & \\
\hline \multirow[t]{8}{*}{ Adaptability } & Wooded UAA per total UAA & 0.61 & 0.65 & 0.16 & 0.98 & 1.00 & Max. \\
\hline & Pasture UAA per total UAA & 0.17 & 0.21 & 0.56 & 0.01 & 0.00 & Min. \\
\hline & Subsidies per total income & 27.20 & 40.17 & 31.68 & 13.88 & 20.46 & C25 \\
\hline & Cattle LU per sheep LU & 0.10 & 0.78 & 0.05 & 0.58 & 0.50 & Rec. \\
\hline & Swine LU per total LU & 0.02 & 0.02 & 0.01 & 0.20 & 0.10 & Rec. \\
\hline & Cows per bull & 29.59 & 35.15 & 23.75 & 22.64 & 22.50 & C25 \\
\hline & Ewes per ram & 35.44 & 32.72 & 28.49 & 26.29 & 23.94 & C25 \\
\hline & Sows per boar & 10.70 & 10.17 & 13.33 & 7.76 & 7.25 & C25 \\
\hline \multirow[t]{8}{*}{ Self-reliance } & Rented UAA per total UAA & 0.48 & 0.34 & 0.35 & 0.05 & 0.00 & Min. \\
\hline & Scrubland UAA per total UAA & 0.15 & 0.05 & 0.10 & 0.00 & 0.00 & Min. \\
\hline & Cultivated UAA per total UAA & 0.05 & 0.08 & 0.13 & 0.01 & 0.19 & P90 \\
\hline & Animal feedstuff & 67.70 & 68.31 & 165.95 & 144.97 & 39.5 & C25 \\
\hline & Veterinary expenses & 9.79 & 9.98 & 18.77 & 19.69 & 3.8 & C25 \\
\hline & Intermediate consumption & 123.97 & 138.76 & 249.63 & 254.94 & 72.9 & C25 \\
\hline & Intraunit consumption & 92.50 & 99.70 & 88.69 & 124.08 & 108.9 & C75 \\
\hline & $\begin{array}{l}\text { Percentage use of natural } \\
\text { resources }\end{array}$ & 69.75 & 74.93 & 60.00 & 58.20 & 83.0 & C75 \\
\hline \multirow[t]{4}{*}{ Equity } & Total AWU of the farm per 100 ha & 0.50 & 0.60 & 1.00 & 0.94 & 0.81 & C75 \\
\hline & Permanent AWU per 100 ha UAA & 0.26 & 0.31 & 0.15 & 0.31 & 0.42 & C75 \\
\hline & Temporary AWU per 100 ha UAA & 0.05 & 0.10 & 0.19 & 0.36 & 0.33 & P90 \\
\hline & Family AWU per 100 ha UAA & 0.19 & 0.19 & 0.66 & 0.27 & 0.38 & C75 \\
\hline \multirow[t]{10}{*}{ Stability } & Owned UAA per total UAA & 0.52 & 0.66 & 0.65 & 0.95 & 1.00 & Max. \\
\hline & Total stocking rate & 0.28 & 0.37 & 0.60 & 0.47 & 0.33 & Rec. \\
\hline & Land fixed capital & 4797.04 & 5170.68 & 4599.63 & 6435.04 & 5646 & C75 \\
\hline & Buildings fixed capital & 420.11 & 735.59 & 766.23 & 1058.84 & 923 & C75 \\
\hline & Machinery fixed capital & 90.59 & 80.06 & 120.52 & 85.76 & 123 & C75 \\
\hline & Breeding livestock fixed capital & 129.27 & 290.86 & 253.47 & 326.00 & 311 & C75 \\
\hline & $\begin{array}{l}\text { Percentage of autochthonous } \\
\text { cattle }\end{array}$ & 0.41 & 0.14 & 0.00 & 0.26 & 1.00 & Max. \\
\hline & $\begin{array}{l}\text { Percentage of autochthonous } \\
\text { sheep }\end{array}$ & 0.66 & 0.55 & 0.38 & 0.66 & 1.00 & Max. \\
\hline & Percentage of Iberian pigs & 0.80 & 0.83 & 0.38 & 1.00 & 1.00 & Max. \\
\hline & No. of montanera fattened pigs & 0.31 & 0.24 & & 0.65 & 0.59 & C75 \\
\hline \multirow[t]{10}{*}{ Productivity } & Sales of livestock & 175.35 & 178.27 & 286.12 & 594.05 & 285 & C75 \\
\hline & Other sales & 29.68 & 23.95 & 66.31 & 21.18 & 38 & C75 \\
\hline & Gross output & 385.12 & 483.10 & 644.58 & 921.75 & 666 & C75 \\
\hline & Net value added & 231.08 & 299.55 & 344.58 & 605.29 & 397 & C75 \\
\hline & Net operating surplus & 193.10 & 270.91 & 307.79 & 516.60 & 375 & C75 \\
\hline & Net entrepreneurial income & 170.63 & 249.76 & 292.86 & 511.38 & 371 & C75 \\
\hline & Profitability rate & 3.09 & 3.93 & 5.46 & 6.25 & 5.54 & C75 \\
\hline & Calves sold per cow & 0.81 & 0.78 & 0.79 & 0.80 & 0.88 & C75 \\
\hline & Lambs sold per ewe & 1.08 & 0.77 & 1.06 & 1.08 & 1.25 & C75 \\
\hline & Piglets sold per sow & 7.24 & 7.30 & 5.33 & 9.35 & 10.75 & C75 \\
\hline
\end{tabular}

${ }^{1}$ UAA indicates utilized agricultural area; LU, livestock unit; AWU, annual work units; max., maximum value; min., minimum value; $\mathrm{C75}$, upper quartile; $\mathrm{C25}$, lower quartile; P90, 90th percentile; and rec., experts' recommendation.

the mixed farms are again the most sustainable and the highstocking rate sheep farms are the least stable.

\section{Productivity}

In Table 2, one observes that as the stocking rate increases, so does the productivity, but it is the marketing of the Iberian pig products that marks the most significant difference for this attribute. Although Group 3 is the most intensified, it has a lower productivity score than Group 4 because it does not breed Iberian pigs. Iberian pigs attain high market prices and produce substantial increases in the farms' profitability indicators.

Figure 2 shows by way of synthesis the comparative evaluation of the sustainability of the four dehesa farm types. 
Table 3. Mean values and significance of the sustainability scores for the four farm types.

\begin{tabular}{|c|c|c|c|c|c|}
\hline \multirow[b]{3}{*}{ Indicators of sustainability $(\%)^{1}$} & \multicolumn{4}{|c|}{ Mean values $^{2}$} & \multirow[b]{3}{*}{ Significance $^{3}$} \\
\hline & Low sheep & Beef & High sheep & Mixed & \\
\hline & $N=19$ & $N=23$ & $N=13$ & $N=14$ & \\
\hline Wooded UAA per total UAA & $61.0 \mathrm{~b}$ & $64.8 \mathrm{~b}$ & $16.0 \mathrm{c}$ & $97.7 \mathrm{a}$ & $0.000^{* * *}$ \\
\hline Pasture UAA per total UAA & $82.8 \mathrm{ab}$ & $78.6 b$ & $43.5 \mathrm{c}$ & $99.2 \mathrm{a}$ & $0.023^{*}$ \\
\hline Subsidies per total income & $84.4 b$ & $54.4 \mathrm{c}$ & $74.0 \mathrm{~b}$ & $100.0 \mathrm{a}$ & $0.000^{* * *}$ \\
\hline Cattle LU per sheep LU & 10.3 & 18.8 & 9.6 & 22.8 & 0.374 \\
\hline Swine LU per total LU & $15.3 b$ & $12.5 b$ & $7.3 b$ & $89.1 \mathrm{a}$ & $0.000^{* * *}$ \\
\hline Cows per bull & 87.7 & 78.0 & 98.0 & 96.2 & 0.391 \\
\hline Ewes per ram & 78.6 & 84.1 & 89.5 & 91.5 & 0.477 \\
\hline Sows per boar & 71.0 & 75.2 & 52.3 & 91.5 & 0.432 \\
\hline Adaptability & $55.0 \mathrm{~b}$ & $52.3 \mathrm{bc}$ & $40.2 \mathrm{C}$ & $86.9 a$ & $0.000^{* * *}$ \\
\hline Rented UAA per total UAA & 51.6 & 66.0 & 64.5 & 95.3 & 0.128 \\
\hline Scrubland UAA per total UAA & 84.9 & 95.3 & 90.1 & 100.0 & 0.544 \\
\hline Cultivated UAA per total UAA & 27.8 & 43.2 & 69.3 & 7.6 & 0.216 \\
\hline Animal feedstuff & $88.9 a$ & $88.6 a$ & $50.1 b$ & $58.4 b$ & $0.000^{* * *}$ \\
\hline Veterinary expenses & $90.8 \mathrm{a}$ & $90.5 \mathrm{a}$ & 77.0ab & $75.6 b$ & $0.059^{\star}$ \\
\hline Intermediate consumption & $88.4 a$ & $85.0 \mathrm{a}$ & $59.8 b$ & $58.5 b$ & $0.000^{* * *}$ \\
\hline Intraunit consumption & $72.2 b c$ & $84.4 b$ & $65.7 \mathrm{c}$ & $100.0 \mathrm{a}$ & $0.000^{* * *}$ \\
\hline Percentage use of natural resources & 82.9 & 86.7 & 72.3 & 70.1 & 0.117 \\
\hline Self-reliance & 73.4 & 80.0 & 68.6 & 73.9 & 0.180 \\
\hline Total AWU of the farm per 100 ha & $60.9 b$ & $65.4 b$ & $92.1 \mathrm{a}$ & $87.1 \mathrm{a}$ & $0.002^{* \star}$ \\
\hline Permanent AWU per 100 ha UAA & 57.5 & 61.8 & 31.6 & 57.5 & 0.508 \\
\hline Temporary AWU per 100 ha UAA & 15.7 & 29.0 & 56.4 & 100.0 & 0.134 \\
\hline Family AWU per 100 ha UAA & $44.5 b$ & $36.4 \mathrm{~b}$ & $87.5 a$ & $63.8 a b$ & $0.009^{\star *}$ \\
\hline Equity & 44.6 & 47.1 & 58.3 & 63.6 & $0.015^{\star}$ \\
\hline Owned UAA per total UAA & 51.6 & 66.0 & 64.5 & 95.3 & 0.128 \\
\hline Total stocking rate & $76.2 \mathrm{a}$ & $81.9 \mathrm{a}$ & $60.3 b$ & $78.8 \mathrm{a}$ & $0.063^{\star}$ \\
\hline Land fixed capital & $83.9 \mathrm{bc}$ & $87.6 \mathrm{c}$ & $74.9 \mathrm{~b}$ & $99.2 \mathrm{a}$ & $0.000^{* * *}$ \\
\hline Buildings fixed capital & $41.5 \mathrm{c}$ & $67.9 b$ & $54.3 \mathrm{c}$ & $87.2 \mathrm{a}$ & $0.001^{* * *}$ \\
\hline Machinery fixed capital & 64.7 & 65.1 & 98.0 & 69.7 & 0.980 \\
\hline Breeding livestock fixed capital & $41.2 b$ & $82.0 \mathrm{a}$ & $79.2 \mathrm{a}$ & $88.0 \mathrm{a}$ & $0.000^{* * *}$ \\
\hline Percentage of autochthonous cattle & 41.0 & 13.6 & 0.0 & 26.3 & 0.562 \\
\hline Percentage of autochthonous sheep & 66.3 & 54.7 & 37.5 & 66.3 & 0.454 \\
\hline Percentage of Iberian pigs & 79.8 & 83.3 & 37.5 & 99.8 & 0.210 \\
\hline No. of montanera fattened pigs & $52.5 b$ & $41.4 b$ & & $90.0 \mathrm{a}$ & $0.019^{*}$ \\
\hline Stability & $59.8 b$ & $65.3 b$ & $65.8 \mathrm{ab}$ & $81.4 a$ & $0.013^{*}$ \\
\hline Sales of livestock & $61.5 b$ & $62.6 b$ & $100.0 \mathrm{a}$ & $100.0 \mathrm{a}$ & $0.000 * * *$ \\
\hline Other sales & 77.3 & 62.3 & 100.0 & 55.1 & 0.187 \\
\hline Gross output & $57.9 d$ & $72.6 \mathrm{c}$ & $96.9 b$ & $100.0 \mathrm{a}$ & $0.000^{\star * *}$ \\
\hline Net value added & $58.2 \mathrm{c}$ & $75.5 b$ & $86.8 b$ & $100.0 \mathrm{a}$ & $0.000^{* * *}$ \\
\hline Net operating surplus & $51.5 \mathrm{c}$ & $72.3 b$ & $82.1 b$ & $100.0 \mathrm{a}$ & $0.000^{* * *}$ \\
\hline Net entrepreneurial income & $46.0 \mathrm{c}$ & $67.4 b$ & $79.0 \mathrm{~b}$ & $100.0 \mathrm{a}$ & $0.000^{* * *}$ \\
\hline Profitability rate & $56.4 \mathrm{c}$ & $70.9 \mathrm{bc}$ & $98.6 a b$ & $100.0 \mathrm{a}$ & $0.001^{* *}$ \\
\hline Calves sold per cow & 91.4 & 88.6 & 89.5 & 90.3 & 0.948 \\
\hline Lambs sold per ewe & 86.4 & 61.4 & 84.8 & 86.5 & 0.101 \\
\hline Piglets sold per sow & 67.3 & 67.9 & 49.6 & 86.9 & 0.431 \\
\hline Productivity & $62.0 \mathrm{c}$ & $71.0 \mathrm{c}$ & $99.3 b$ & $100.0 \mathrm{a}$ & $0.000 * \star \star$ \\
\hline Total sustainability score & $59.0 \mathrm{~b}$ & $63.1 \mathrm{~b}$ & $66.4 b$ & $85.9 \mathrm{a}$ & $0.000^{* * *}$ \\
\hline
\end{tabular}

${ }^{1} \mathrm{UAA}$ indicates utilized agricultural area; LU, livestock unit; and AWU, annual work units.

${ }^{2}$ Lowercase $a, b, c$, and $d$ values with a different letter on the same row are different.

${ }^{3 *} P<0.05,{ }^{* *} P<0.01,{ }^{* * *} P<0.001$. 


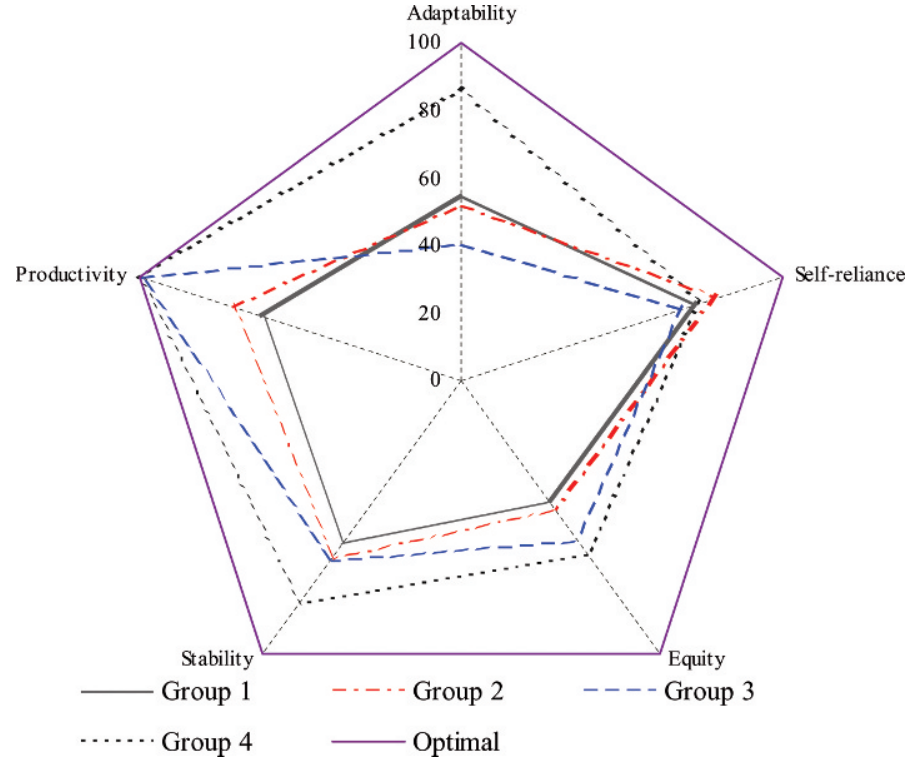

Figure 2. AMOEBA representation of the evaluation of sustainability in terms of its five attributes. The plotted values are the means of the indicators comprising each attribute.

One observes that the mixed livestock group comes closest to the optimal value in most of the sustainability attributes. The high-stocking rate sheep farms are those that least approximate the optimal levels except for the productivity attribute. The scores of Groups 1 and 2 are similar to each other in most attributes.

In sum, for all the attributes save self-reliance, the group of mixed livestock dehesa farms scored the highest sustainability. These farms are the closest to the traditional systems in having a highly diverse production. Their use of resources is optimal, but their stocking rates have departed from the traditional structure. Although this group of farms is currently a minority ( $14 \%$ of the sample), the numbers could rise in the future if strategies for improvement include fattening of the Iberian pig. The farms of Group 3 (highly intensified sheep production) account for $11.6 \%$ of the sample. Although this group presents good economic results and is the most productive after Group 4 , it is very limited with respect to adaptability.

The recent reforms to the CAP, such as cross-compliance and changes in prices in the sheep sector, may be critical for these farms, so that they will, at some time, have to face the need to modify their farming systems. This group also has stocking rates far above what these systems can support, and could therefore be considered at a critical point due to overgrazing (Thompson and Nardone 1999).

The farms of Groups 1 and 2 make use of their resources on the basis of a minimal expenditure in labor and in purchases of external raw materials. Both groups are therefore considered to be the most self-reliant, as they depend to a lesser extent on external inputs, but they are also the two that are most dependent on subsidies. These farms have the lowest stocking rates, and consequently the poorest economic results, as is shown by their income indicators, which are significantly lower than those of the other groups.

Although it is true that the payments that these farms receive may decline in the context of the new CAP, they could possibly compensate this reduction with new aids such as rural development, production of quality food items, organic production, etc. The autochthonous breeds that they farm and their appropriate stocking rates (with no overgrazing) could be considered as desirable objectives for the other groups.

\section{IMPLICATIONS}

The indicator-based comparative evaluation of the sustainability of different types of farms has allowed us to establish levels of sustainability in technical-economic terms for dehesa systems. Mixed dehesas (beef cattle-sheep-Iberian pig) have been found to be the most sustainable, obtaining the highest scores in productivity, adaptability, stability, and equity. These are highly diversified systems and depend little on external subsidies. In the present context, with the uncertainties about the European Union subsidies, this type of farm-very close to a traditional dehesa farm-should be ideal for dehesa farmers. Although the breeding of different livestock species on the same farm makes its management more complex, the overall effect on dehesas has been highly positive: beef cattle, sheep, and Iberian pig complement each other for a better use of the system's resources: the ruminants make use of the pasture, stubble, and fallow land and Iberian pigs in their final phase of fattening for market feed free-range on the pasture and on mast from the holm oaks principally, but also from gall and cork oaks. Even though more labor is needed, farms' profitability has improved, both being aspects of great importance for the sustainability of this ecosystem.

Overgrazing and tree cover are also key issues for the sustainability of dehesas. The presence of holm and cork oaks diversifies the system, both with respect to the goods produced (cork, charcoal, etc.) and to future production alternatives (tourism, game, etc.). Farmers must be aware of this, and work for the improvement and regeneration of their trees. With respect to the intensification of these systems and the resulting overgrazing, managers cannot forget that, although currently those dehesas with higher stocking rates are the most profitable, they are also the least sustainable. When it comes to systems such as dehesas, which may take centuries to regenerate, we cannot afford to take any risks that might damage the ecosystem permanently.

\section{LITERATURE CITED}

Bignal, E. M., D. I. McCracken, and H. Corrie. 1995. Defining European lowintensity farming systems: the nature of farming. In: D. I. McCracken, E. M. Bignal, and S. E. Wenlock [EDS.]. Farming on the edge: the nature of traditional farmland in Europe. Peterborough, United Kingdom: Joint Nature Conservation Committee. p. 29-37.

BoyazogLu, J. 2002. Livestock research and environmental sustainability with special reference to the Mediterranean basin. Small Ruminant Research 45:193-200.

Capillon, A., and D. Genevieve. 2000. Framework for diagnosis of the sustainability of agriculture, from the plot up to the regional level. In: W. Doppler and J. Calatrava [EDS.]. Technical and social systems approaches for sustainable rural development. Weikersheim, Germany: Margraf Verlag. p. 124-128.

Colson, F., And V. Chatellier. 1996. Les exploitations bovines françaises sont parmi les plus extensives de l'Union européenne. INRA Productions Animales 9(4):273-284. 
Conway, G. R. 1994. Sustainability in agricultural development: trade-offs between productivity, stability and equitability. Journal for Farming Systems and Research-Extensions 4(2):1-14.

Díaz, M., P. Campos, and F. J. Pulido. 1997. The Spanish dehesas: a diversity in land-use and wildlife. In: D. J. Pain and M. W. Pienkowski [EDs.]. Farming and birds in Europe. The common agricultural policy and its implications for bird conservation. London, United Kingdom: Academic Press. p. 178-209.

Escribano, M., P. Gaspar, F. Pulido, A. Rodríguez de Ledesma, and F. J. Mesías. 2006. Análisis económico de las explotaciones extremeñas de dehesa a través de indicadores de capital, costes, producciones y rentabilidad. In: M. Espejo, M. Martin, C. Matos, and F. J. Mesias [EDS.]. Gestión ambiental y económica del ecosistema dehesa en la Península Ibérica. Mérida, Spain: Junta de Extremadura, Consejería de Infraestructuras y D.T. p. 339-350.

Escribano, M., A. Rodríguez, F. J. Mesías, and F. Pulido. 2001. Farm size effect on economic indicators in extensive sheep farms. Livestock Research for Rural Development 13:1-6.

Escribano, M., A. Rodríguez, F. J. Mesías, and F. Pulido. 2002a. Niveles de cargas ganaderas en la dehesa extremeña. Archivos de Zootecnia 51(195):315-326.

Escribano, M., A. Rodríguez, F. J. Mesías, and F. Pulido. 2002b. Stocking rate and capital indicators in extensive sheep farms (SW Spain). Archivos de Zootecnia 51(196):457-460.

Espejo, M., And A. M. Espejo. 2006. Los sistemas tradicionales de explotación y la aplicación de innovaciones tecnológicas de la dehesa. In: M. Espejo, M. Martin, C. Matos, and F. J. Mesias [EDS.]. Gestión ambiental y económica del ecosistema dehesa en la Península Ibérica. Mérida, Spain: Junta de Extremadura, Consejería de Infraestructuras y D.T. p. 177-200.

European Communities. 2000. Manual on the economics accounts for agriculture and forestry EAA/EAF 97 (Rev 1.1). Luxembourg, Luxembourg: Office for Official Publications of the European Communities. $181 \mathrm{p}$.

Gaspar, P., M. Escribano, F. J. Mesías, A. Rodríguez de Ledesma, and F. Pulido. 2008. Sheep farms in the Spanish rangelands (dehesas): typologies according to livestock management and economic indicators. Small Ruminant Research 74:52-63.

Gaspar, P., F. J. Mesías, M. Escribano, A. Rodríguez de Ledesma, and F. Pulido. 2007. Economic and management characterization of dehesa farms: implications for their sustainability. Agroforestry Systems 71:151-162.

Gibon, A., A. R. Sibbald, J. C. Flamant, P. Lhoste, R. Revilla, R. Rubino, and J. T. Sørensen. 1999. Livestock farming systems research in Europe and its potential contribution for managing towards sustainability in livestock farming. Livestock Production Science 61:121-137.

Granda, M., V. Moreno, and P. M. Prieto. 1991. Pastos naturales en la dehesa extremeña. Badajoz, Spain: SIA-Junta de Extremadura. 23 p.

Hernández, C. G. 1998. Ecología y fisiología de la dehesa. In: C. G. Hernández [ed.]. La dehesa, aprovechamiento sostenible de los recursos naturales. Madrid, Spain: Editorial Agricola Española. p. 53-94.

Joffre, R., S. Rambal, and J. P. Ratte. 1999. The dehesa system of southern Spain and Portugal as a natural ecosystem mimic. Agroforestry Systems 45:57-79.

LASSEUR, J. 2005. Sheep farming systems and nature management of rangeland in French Mediterranean mountain areas. Livestock Production Science 96:87-95.

López-Ridaura, S., O. Masera, and M. Astier. 2002. Evaluating the sustainability of complex socio-environmental systems: the MESMIS framework. Ecological Indicators 2(1-2):135-148.

López-Ridaura, S., H. Van Keulen, M. K. Van Ittersum, and P. A. Leffelaar. 2005. Multiscale methodological framework to derive criteria and indicators for sustainability evaluation of peasant natural resource management systems. Environment, Development and Sustainability 7:51-69.

[MAPA] Ministerio de Agricultura, Pesca y Alimentación. 1987-2005. Anuarios de Estadística Agraria y Agroalimentaria. Madrid, Spain: Secretaria General
Técnica del Ministerio de Agricultura, Pesca y Alimentación, Ministerio de Agricultura, Pesca y Alimentación.

Masera, O., S. Astier, and S. López-Ridaura. 1999. Sustentabilidad y manejo de los recursos naturales. El marco de evaluación MESMIS. México, México: MundiPrensa, S.S., Gira, IE-UNAM. 109 p.

Milán, M. J., E. Arnalte, and G. Caja. 2003. Economic profitability and typology of Ripollesa breed sheep farms in Spain. Small Ruminant Research 49: 97-105.

Milán, M. J., J. Bartolomé, R. Quintanilla, M. D. García-Cachán, M. Espejo, P. L. Herraiz, J. M. Sánchez-Recio, and J. Piedrafita. 2006. Structural characterisation and typology of beef cattle farms of Spanish wooded rangelands (dehesas). Livestock Science 99:197-209.

Mitchell, G., A. May, and A. McDonald. 1995. PICABUE: a methodological framework for the development of indicators of sustainable development. International Journal of Sustainable Development and World Ecology 2:104-123.

Montero, G., A. San Miguel, and I. Cañellas. 1998. Sistemas de selvicultura mediterránea. La dehesa. In: R. M. Jiménez Díaz and J. Lamo de Espinosa [EDS.]. Agricultura sostenible. Madrid, Spain: Mundi-Prensa. p. 519-554.

Nahed, J., J. M. Castel, Y. Mena, and J. Caravaca. 2006. Appraisal of the sustainability of dairy goat systems in southern Spain according to their degree of intensification. Livestock Science 101:10-23.

Olea, L., and A. San Miguel-Ayanz. 2006. The Spanish dehesa. A traditional Mediterranean silvopastoral system linking production and nature conservation. In: J. Lloveras, A. Gonzalez-Rodriguez, 0. Vazquez-Yañez, J. Piñeiro, 0. Santamaria, L. Olea, and M. J. Poblaciones [EDs.]. Sustainable grassland productivity. Grassland science in Europe. Volume 11. Badajoz, Spain: Sociedad Española para el Estudio de los Pastos. p. 3-13.

Peco, B., A. M. Sánchez, and F. M. Azcárate. 2006. Abandonment in grazing systems: consequences for vegetation and soil. Agriculture, Ecosystems and Environment 113:284-294.

Plieninger, T., J. Modolell y Mainou, and W. Konold. 2004. Land manager attitudes toward management, regeneration, and conservation of Spanish holm oak savannas (dehesas). Landscape and Urban Planning 66:185-198.

Plieninger, T., and C. Wilbrand. 2001. Land use, biodiversity conservation, and rural development in the dehesas of Cuatro Lugares, Spain. Agroforestry Systems 51:23-34.

Porras, C. J. 2000. Estudio técnico económico de explotaciones ganaderas extensivas 1997-1999. Sevilla, Spain: Consejería de Agricultura y Pesca, Junta de Andalucía. $129 \mathrm{p}$.

Ronchi, B., and A. Nardone. 2003. Contribution of organic farming to increase sustainability of Mediterranean small ruminants livestock systems. Livestock Production Science 80:17-31.

San Miguel, A. 1994. La dehesa española: origen, tipología, características y gestión. Madrid, Spain: Fundación Conde Valle de Salazar. 96 p.

SCHNABEL, S. 1997. Soil erosion and runoff production in a small watershed under silvo-pastoral landuse (dehesa) in Extremadura, Spain. Logroño, Spain: Geoforma Ediciones. 167 p.

Serrano, E., P. Lavín, F. J. Giradles, A. Bernues, and A. Ruíz. 2004. Classification variables of cattle farms in the mountains of León, Spain. Spanish Journal of Agricultural Research 2(4):504-511.

Smith, A. J., and J. Dumanski. 1994. FESLM: An international framework for evaluating sustainable land management. Rome, Italy: World Soil Resources Report 73. Food and Agriculture Organisation of the United Nations. 83 p.

Ten Brink, B. J. E., S. H. Hosper, and F. Colin. 1991. A quantitative method for description and assessment of ecosystems: the AMOEBA approach. Marine Pollution Bulletin 23:265-70.

Thompson, P. B., And A. Nardone. 1999. Sustainable livestock production: methodological and ethical challenges. Livestock Production Science $61: 111-119$ 